Cano, M. F., \& Murillo-García, O. E. (2021). Time partitioning among neotropical frugivorous bats: effects of phylogeny, body size, and abundance. Revista de Biología Tropical, 69(4), 1149-1163. https://doi.org/10.15517/rbt.v69i4.47487

Biologín Tropical

VERTEBRATE BIOLOGY

https://doi.org/10.15517/rbt.v69i4.47487

\title{
Time partitioning among neotropical frugivorous bats: effects of phylogeny, body size, and abundance
}

\author{
Manuel Francisco Cano ${ }^{1 *}$; (D) https://orcid.org/0000-0002-0238-1762 \\ Oscar E. Murillo-García ${ }^{1}$; (iD https://orcid.org/0000-0001-5040-7894
}

1. Grupo de Ecología Animal, Departamento de Biología, Universidad del Valle, Cali, Valle del Cauca, Colombia; manuel.cano@correounivalle.edu.co (*Correspondence), oscar.murillo@correounivalle.edu.co

Received 18-VI-2021. Corrected 20-IX-2021. Accepted 13-X-2021.

\begin{abstract}
Introduction: Resource partitioning by promoting coexistence is essential to determine species richness and composition in natural communities. However, the partitioning of time has been questioned as a mechanism that promotes the coexistence of ecologically similar species.

Objective: To determine the importance of the partitioning of time as a mechanism that promotes coexistence, we compared the activity patterns of tropical frugivorous bats.

Methods: We captured bats with mist nets from sunset to sunrise in three study sites (tropical dry forest, wet forest, and rainforest) to calculate activity patterns of the species using Kernel density estimation. We used the superposition coefficient $\left(\Delta_{1}\right)$ to compare activity patterns between (1) bat assemblages of study sites, (2) frugivorous species in the same site, and (3) populations of the same species among different sites. To determine whether the overlap in the activity patterns was related to the ecological similarity of species, we evaluated the association between $\Delta_{1}$ and similarity in abundances and body mass and phylogenetic closeness.

Results: We found geographical variations in the overall activity patterns of the assemblages of the three localities. Likewise, we found variations in activity patterns between species at each study site and between populations in different study sites. Overlap in activity patterns tended to decrease as species were phylogenetically more closely related and similar in abundance and body size.

Conclusions: Our results provide empirical support for the role of temporal segregation in activity patterns as a mechanism that promotes the coexistence of ecologically similar species in nature.
\end{abstract}

Key words: competition; niche overlapping; temporal segregation; ecological segregation; ecologically similar species; species coexistence.

Interspecific interactions are essential to determine species richness and composition in natural communities (Chase \& Leibold, 2003; Colorado-Zuluaga, 2015; Diamond, 1975). In particular, competition is considered a critical interaction since its reduction or avoidance promotes resource partitioning of ecologically similar species (Holt, 2001; Klatt et al., 2015). Thus, temporal and spatial segregation of ecologically similar species can result from the effect of interspecific competition, which may have ecological and evolutionary implications by constituting a mechanism that allows coexistence between species and, so, affecting the structure of biological communities (Kronfeld-Schor \& Dayan, 2003). The removal of an ecologically similar species leads to changes in the temporal activity patterns 
and habitat use of competing species (Ziv et al., 1993), suggesting temporal segregation; however, it is considered less common than dietary specialization and spatial segregation (Schoener, 1974). Consequently, the ecological significance of segregation in temporal activity to facilitate the coexistence of species is still controversial (Zeppelini et al., 2017), and this segregation is usually associated with the circadian rhythms of species (Kronfeld-Schor \& Dayan, 2003).

The temporal activity patterns of species can vary across their geographic ranges in response to biotic and abiotic factors (Vieira et al., 2017). In small mammals, the degree of flexibility in the temporal activity pattern is associated with predation risk, so species with a higher predation risk tend to have less flexible activity patterns (Halle \& Stenseth, 2000). Besides, abiotic factors (such as temperature, precipitation, and photoperiod) tend to influence the activity patterns of certain groups of organisms (Kronfeld-Schor \& Dayan, 2003; Vieira et al., 2017), with different effects and magnitudes depending on the animal group (Vieira et al., 2017). Variations in the daily activity patterns of species between locations possibly reflect fluctuations in food availability or foraging strategies (O'Donnell, 2010; Vieira et al., 2017). Due to the multiple factors that can influence the temporal activity of species, assessing the importance of temporal segregation as a mechanism of coexistence requires understanding spatial and temporal variation in activity patterns of ecologically diverse groups. However, partitioning of time among species has been less studied than spatial partitioning.

Bats are highly diverse, abundant, and ecologically important in tropical forests; thus, understanding their activity patterns can help unravel the mechanisms that determine the local diversity of assemblages. Temporal activity patterns are known for some species of Neotropical bats (Brown, 1968; Rocha et al., 2020; Zeppelini et al., 2017), vary spatially, and are influenced by the availability of resources: vegetation structure, nectar availability, energy requirements, and activity patterns of their preys (Kunz, 1973; Rothenwöhrer et al., 2011). For insectivorous bats, the temporal variation in activity patterns is related to the temporal distribution of insects (Hagen \& Sabo, 2014; Kuenzi \& Morrison, 2003; Speakman et al., 2000). For canopy frugivores, there are regulatory factors of the activity patterns as climatic seasons and lunar cycles, mainly associated with full moon nights (Lang et al., 2005; Santos-Moreno et al., 2010; Zeppelini et al., 2019) and several unpredictable factors such as precipitation and environmental disturbance (López-González et al., 2012; Milne et al., 2005). However, despite the high local richness of bats, time partitioning as a mechanism structuring bat assemblages remains poorly studied.

Neotropical frugivorous bats, in particular, are a rich local guild with a high potential for niche overlap and interspecific competition, resulting from a close phylogenetic relationship since all species belong to the Phyllostomidae family. Thus, studying Neotropical frugivorous bats' activity patterns can help to understand the mechanisms that allow the coexistence of species in highly diverse assemblages. For bats of Carolliinae subfamily, differences in nocturnal activity among closely related have been reported (Bonaccorso et al., 2007; Delaval et al., 2005). Besides, base on a high spatial overlap on foraging sites, the differences in mean emergence time among Carollia castanea y $C$. brevicauda seem to avoid competition and suggests the existence of exploitative competition between them (Bonaccorso et al., 2007). However, comparisons of activity patterns between pairs of closely related species have concluded that the activity peaks of fruit bats have not evolved to reduce competition between them (Aguiar \& Marinho-Filho, 2004; Zeppelini et al., 2017). Hence, empirical studies are needed to fully understand the importance of segregation in temporal activity as a mechanism that, by reducing competition, promotes coexistence in bat assemblages.

To understand the importance of time partitioning for the coexistence of ecologically similar species, we studied the temporal activity patterns of assemblages of Neotropical 
frugivorous bats in three ecosystems (tropical dry forest, wetforest, and rainforest). We compared the degree of overlap in temporal activity at different levels: A) Community, contrasting assemblages between study areas; B) interspecific, comparing species inside each of the assemblages; and C) intra-specific, comparing the same species between study areas. We compared temporal activity by estimating the degree of overlap in hourly activity between species pairs. Additionally, we evaluated the association between the degree of overlap in temporal activity and the differences in body size, abundance, and phylogenetic relationship at each site. We predict that: (1) the temporal overlap between assemblages of bats will be low, indicating that temporal activity patterns will be different between assemblages due to adjusting of species to contrasting local environmental and biotic conditions between sites (O'Donnell, 2010; Vieira et al., 2017; Vilella et al., 2020); (2) in each site, the overlap in temporal activity of species will decrease as species are more similar in size, abundance, or phylogenetically (Castro-Arellano \& Lacher,
2009; Nagy-Reis et al., 2018) and (3) the temporal overlap between populations of the same species will be low, indicating that temporal activity patterns of the same species will differ between sites due to adjusting of species to contrasting local biotic and abiotic conditions between sites (O'Donnell, 2010; Vieira et al., 2017; Vilella et al., 2020).

\section{MATERIALS AND METHODS}

Study area: The research was carried out in three study sites that, according to Holdridge (1967), represent different life zones in Valle del Cauca, Colombia (Fig. 1). 1) El Vínculo Regional Natural Park (350'12" N \& $\left.76^{\circ} 17^{\prime} 58^{\prime \prime} \mathrm{W}\right)$ : A protected fragment of tropical dry forest of 83 ha (Funagua, 2010) with wooded areas in different stages of natural regeneration such as intervened primary forest (Bp-i), secondary forest (Bs), and scrub (M) (CadeloCabrera \& Parra-Valencia, 2007). El Vínculo has altitudes between 997 and $1150 \mathrm{~m}$ above sea level (m.a.s.l.), an average temperature of $25^{\circ} \mathrm{C}$, and an annual rainfall of $1380 \mathrm{~mm}$.

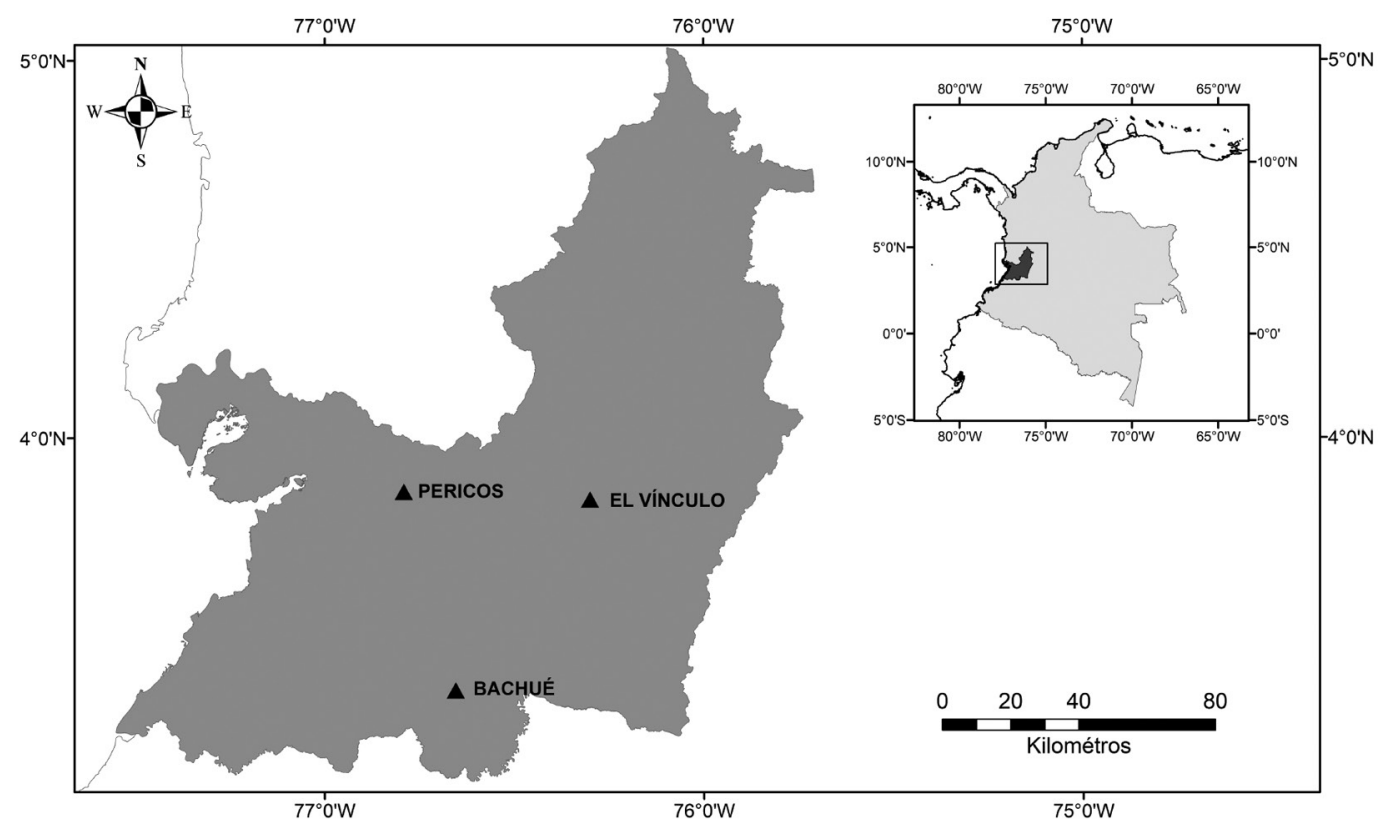

Fig. 1. Study area showing sampling sites. Dry forest (El Vínculo Regional Park), wet forest (Pericos Community Reserve), and rainforest (Bachué Reserve). 
2) Pericos Natural Reserve (350'39” N \& $76^{\circ} 47^{\prime} 22$ " W): A community-managed reserve that contains an extensive area of wet forest (440 ha) in the Choco Biogeographic region, on the Western slope of the Western mountain range of the Andes. The reserve is located in the Dagua river basin at 500 m.a.s.l., has a high annual rainfall of above $5000 \mathrm{~mm}$, and temperatures above $24^{\circ} \mathrm{C}$ (Funagua, 2010). 3) Bachué Nature Reserve ( $\left.3^{\circ} 19^{\prime} 50^{\prime \prime} \mathrm{N} \& 7^{\circ} 39^{\prime} 15^{\prime \prime} \mathrm{W}\right)$ : A private reserve of 2000 ha of rainforest with intervened primary and secondary forest areas in the Tropical Andes region. It is located in the Farallones de Cali National Natural Park buffer zone at 1800 m.a.s.l., at the confluence of the Pato and Pance rivers. The temperature varies from 16 to $24{ }^{\circ} \mathrm{C}$ and has an annual rainfall between 2000 and $3000 \mathrm{~mm}$ (Fundación Farallones, 2013).

Sampling method: We sampled bats between July and October 2018 using mist nets. Each study site was sampled once at nighttime for a total sampling of 44 nights: 15 nights at the Vínculo and Pericos and 14 nights at Bachué. To determine the activity patterns of the frugivorous bats, we captured specimens using ten mist-nets $(2.5 \times 12 \mathrm{~m})$ for a total of $158400 \mathrm{~m}^{2}$-net/h in the localities: 54000 $\mathrm{m}^{2}$-net/h in Vínculo and Pericos, and 50400 $\mathrm{m}^{2}-$ net/h in Bachué.

The mist nets were deployed in areas suitable for bat captures, such as forest clearings, trails, and water sources. We relocated them every two nights to include the variation in vegetation cover of each locality. The nets were checked hourly, from 18:00 to $6: 00 \mathrm{~h}$, due to the low catch rates of individuals. However, in case of rain, intervals of net checking were shorter, or nets were closed. We kept all captured individuals in cloth bags and classified them taxonomically using a field guide from South America (Díaz et al., 2016). Additionally, the weight of each individual was recorded and considered as a surrogate of body size. To avoid pseudo-replication, individuals were marked with haircuts in the lower dorsal region (close to the uropatagium). Finally, we fed individuals with fruit compote before being released. The study was covered by the permit for the sampling and handling of wild animals $1070(28 / 08 / 2015)$ issue by National Authority for Environmental Licenses (ANLA) to Universidad del Valle. All applicable international, national, and institutional guidelines for the care and use of animals were followed.

Data analysis: We used the distribution that describes the probability of capture within any particular hourly interval of the day to characterize the temporal activity patterns. Thus, we used the probability density function, calculated with the Kernel method of the overlap R-package (Meredith \& Ridout, 2017), to describe activity patterns. First, we calculated the activity pattern for each assemblage of frugivorous bats (by adding all the capture data from a given site) and for each species at each locality. For analysis, we only considered species with at least ten records. Posteriorly, we quantified the extent of overlap between the correspondent estimated distributions of two assemblages or species to compare activity patterns. The overlapping coefficient $\left(\Delta_{1}\right)$ quantifies the area of overlap between pairs of density curves and is recommended for small sample sizes (less than 50 records per species) (Meredith \& Ridout, 2014). So, we used $\Delta_{1}$ to quantify the differences in hourly activity between assemblages or species. This coefficient varies between 0 (no overlap) and 1 (complete overlap) (Linkie \& Ridout, 2011; Meredith \& Ridout, 2017). Finally, we generated $95 \%$ confidence intervals for $\Delta 1$ using the Bootstrap method from 1000 repetitions (Meredith \& Ridout, 2014). Then, we used these confidence intervals to determine whether activity patterns were different (between assemblages and populations of species in various sites) or whether temporal segregation was present (between species at each site). Between sympatric species of genus Carollia, the early emergence of 14 min for the small species $(C$. castanea) is enough to foraging, avoiding competition with the more dominant and larger species (C. brevicauda) (Bonaccorso 
et al., 2007). Thus, we considered differences or temporal segregation when the upper levels of confidence intervals for the overlap index were less than 0.9 , indicating that the activity patterns diverged by at least $10 \%$.

To determine whether the overlap in the activity patterns was related to the ecological similarity of species, we evaluated the association between $\Delta_{1}$ and similarity in abundances and body mass and phylogenetic closeness. For this, we calculated matrices of similarity in activity patterns $\left(\Delta_{1}\right)$, differences in body mass and abundance, and phylogenetic distance for each pair of species at each site. We calculated the abundance matrix based on the differences in captures between species from the same locality, the body size matrix based on the difference in average body mass between each pair of species, and the phylogenetic matrix based on the patristic distances (index of phylogenetic distance) between species pairs using a phylogeny of Noctilionoidea superfamily (Rojas et al., 2016), which includes more than $90 \%$ of genera and $76 \%$ of the superfamily species. Finally, to determine the degree of association of the temporal overlap matrix with the matrices of abundance, body size, and phylogenetics, we performed Mantel tests using the vegan package (Oksanen et al., 2017) in the R programming language (R Core Team, 2017).

\section{RESULTS}

A total of 21 species (350 individuals) of frugivorous bats were captured. The highest species richness was found in the site of wet forest (Pericos: 13 species), followed by the site of rainforest (Bachué: 10 species), and the site of dry forest (El Vínculo: 7 species). Frugivorous bats of the genera Carollia and Artibeus obtained the highest number of records in the wet forest and dry forest sites, while those of genus Sturnira were dominant in the rainforest site. Small frugivorous bats, such as those of genus Vampyressa, had a low number of captures (Table 1).

\section{TABLE 1}

Species richness and abundance of frugivorous bats in El Vínculo (dry forest), Pericos (wet forest), and Bachué (rainforest) study sites

\begin{tabular}{lccc}
\hline \multirow{2}{*}{ Species (sp. / spp.) } & \multicolumn{3}{c}{ Locality } \\
\cline { 2 - 4 } & El Vínculo & Pericos & Bachué \\
\hline Artibeus aequatorialis & 0 & 16 & 0 \\
Artibeus jamaicensis & 0 & 3 & 0 \\
Artibeus lituratus & 26 & 0 & 2 \\
Artibeus planirostris & 22 & 0 & 0 \\
Carollia brevicauda & 3 & 16 & 50 \\
Carollia castanea & 0 & 27 & 1 \\
Carollia perspicillata & 10 & 16 & 1 \\
Dermanura anderseni & 0 & 0 & 8 \\
Dermanura Phaeotis & 1 & 16 & 0 \\
Dermanura sp 1 & 3 & 0 & 0 \\
Dermanura sp 2 & 0 & 12 & 0 \\
Enchistenes hartii & 0 & 0 & 2 \\
Platyrrhinus chocoensis & 0 & 3 & 0 \\
Platyrrhinus dorsalis & 0 & 7 & 1 \\
Rhinophylla alethina & 0 & 21 & 0 \\
Sturnira bogotensis & 0 & 0 & 20 \\
Sturnira erythromos & 0 & 0 & 2 \\
Sturnira koopmanhilli & 0 & 1 & 0 \\
Sturnira ludovici & 0 & 0 & 41 \\
Sturnira parvidens & 0 & 0 & 2 \\
Uroderma convexum & 10 & 1 & 0 \\
Vampyressa thyone & 0 & 6 & 0 \\
Total & 75 & 145 & 135 \\
\hline
\end{tabular}

The activity patterns of assemblages of frugivorous bats were variable among sites. The assemblage at the dry forest showed a bimodal pattern, with activity peaks during the first two hours after sunset and the last two hours before sunrise (Fig. 2A). On the other hand, the activity patterns of the wet forest and rainforest assemblages were unimodal, with a peak of activity during the first hours of the night and a gradual decrease in activity (Fig. 2B, Fig. 2C) respectively. The observed overlap coefficients $(\Delta 1)$ in hourly activity was lower between the sites with unimodal activity pattern than between them and the site with bimodal pattern: Wet forest - dry forest $(\Delta 1=$ $0.675, \mathrm{IC}=0.555-0.751)$, wet forest - rainforest $(\Delta 1=0.791, \mathrm{IC}=0.612-0.838)$ and dry forest - rainforest $(\Delta 1=0.588, \mathrm{IC}=0.444-0.652)$. 

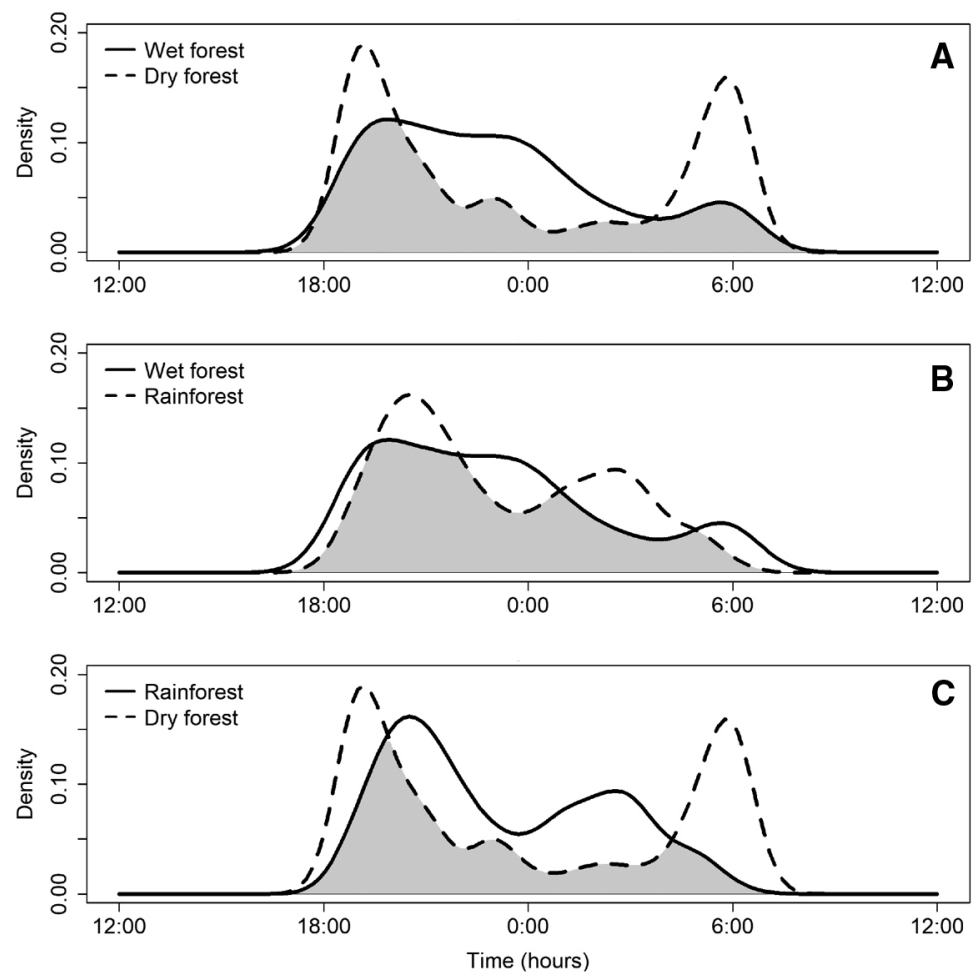

Fig. 2. Estimates of activity patterns overlap for frugivorous bat assemblages between different ecosystems: Dry forest (E1 Vínculo Regional Park), wet forest (Pericos Community Reserve), and rainforest (Bachué Reserve). Comparison between A. Wet forest and dry forest $\mathbf{B}$. Wet forest and rainforest $\mathbf{C}$. Rainforest and dry forest. The shaded area represents the overlap coefficient $(\Delta 1)$.

The overlap in temporal activity patterns between sympatric species of frugivorous bats (Table 2) was high and variable. At the dry forest of El Vínculo, the observed overlap coefficients $(\Delta 1)$ in hourly activity were on average $0.76 \pm 0.06$ with a difference greater than $10 \%$ for all pairs of species (upper level of confidence intervals less than 0.9); except for Carollia perspicillata and Artibeus lituratus (Table 2).
At the wet forest of Pericos, the observed overlap coefficients were on average 0.70 \pm 0.16 , with 20 out of the 27 comparisons between species differing by more than $10 \%$ (confidence intervals with values lower than 0.9) (Table 3). This difference was especially marked between Rhinophylla alethina and Carollia castanea since the confidence interval for $\Delta 1$ was the lowest $(\Delta 1=0.530$, IC $=0.359$ 0.800 ) (Table 3 ), indicating a difference of

TABLE 2

Mean hourly overlap (95\% confidence interval) in temporal activity between the most abundant species of frugivorous bats in a dry forest (El Vínculo Regional Park)

\begin{tabular}{lcccc}
\hline \multicolumn{1}{c}{ Species (sp.) } & Artibeus lituratus & Artibeus planirostris & Carollia perspicillata & Uroderma convexum \\
\hline Artibeus lituratus & 1 & $0.708(0.452-0.850)$ & $0.878(0.500-0.907)$ & $0.748(0.408-0.862)$ \\
Artibeus planirostris & & 1 & $0.714(0.366-0.851)$ & $0.766(0.391-0.882)$ \\
Carollia perspicillata & & & 1 & $0.737(0.325-0.847)$ \\
Uroderma convexum & & & & 1 \\
\hline
\end{tabular}




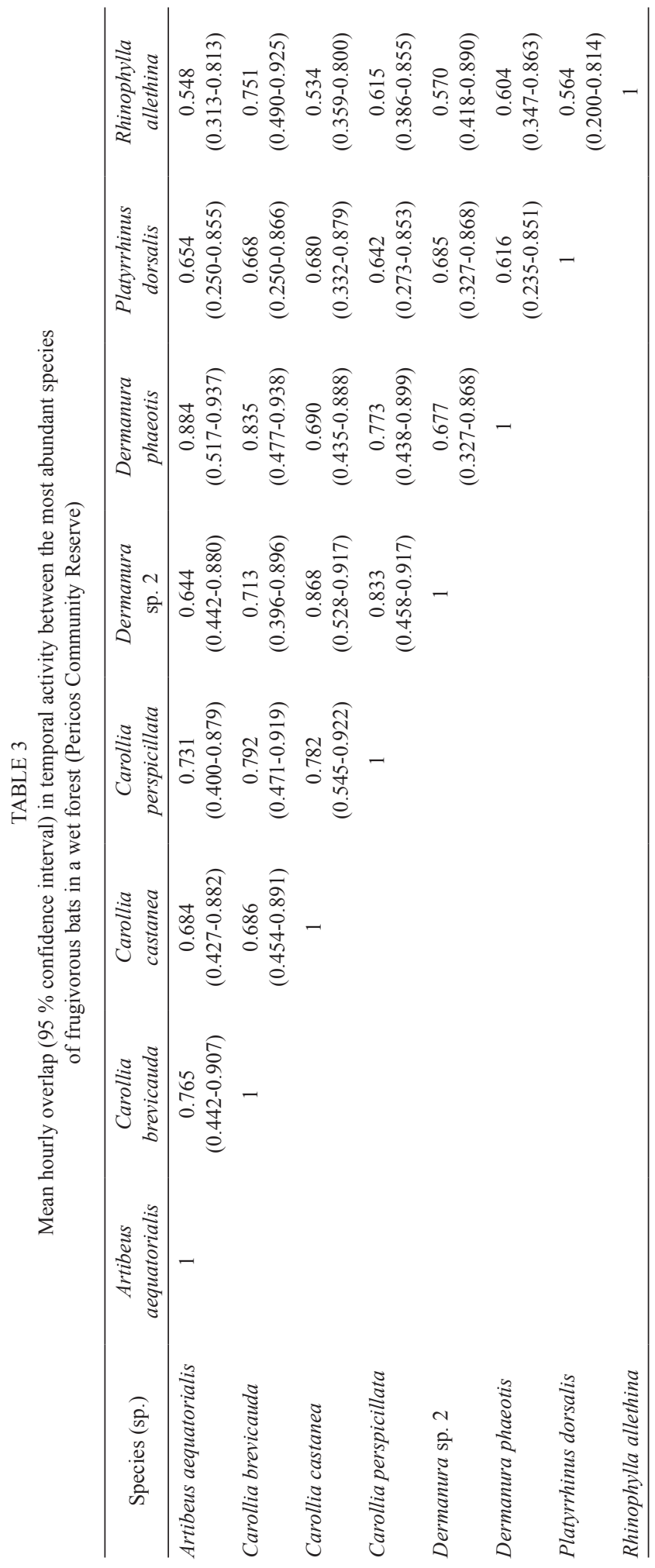




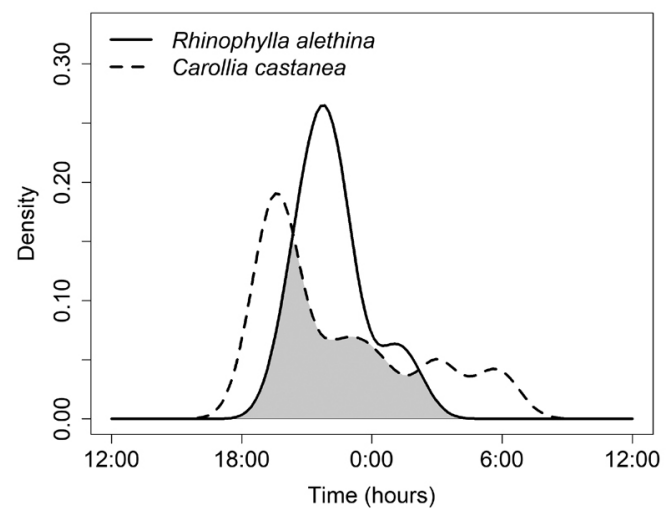

Fig. 3. Estimates of activity patterns overlap for $R$. alethina y $C$. castanea in the site of wet forest (Pericos Community Reserve). The shaded area represents the overlap coefficient $(\Delta 1)$.

more than $20 \%$ in the activity patterns of these two species. This marked segregation between the activity patterns of both species is because the peak activity of $R$. alethina occurs around 21:00 h, when the activity of $C$. castanea has decreased (Fig. 3).

Finally, at the rainforest of Bachué, the average overlap coefficient was $0.67 \pm 0.11$, with differences greater than $10 \%$ between the two species of Sturnira ( $S$. bogotensis and $S$. ludovici) and between them and C. brevicauda (Table 4). The overlap was particularly lower between $S$. bogotensis and $S$. ludovici $(\Delta 1=$ 0.456$, IC $=0.269-0.677)$. The activity of $S$. bogotensis is restricted to the first four hours at night (18:00-22:00 h), while $S$. ludovici increases after $21: 00 \mathrm{~h}$ and remains relatively constant until before dawn (Fig. 4).

We found contrasting activity patterns between populations of the same species from different locations. For Carollia perspicillata, we found a difference greater than $10 \%$ in temporal activity between Pericos and El Vínculo populations $\left(\Delta_{1}=0.695, \mathrm{CI}=0.415-0.896\right)$, with El Vínculo individuals exhibiting a second activity peak just before the dawn that was not observed in Pericos (Fig. 5A). However, Carollia brevicauda's activity patterns did not differ between Pericos and Bachué $\left(\Delta_{1}=0.800\right.$, CI $=0.498-0.924)$, with both populations having

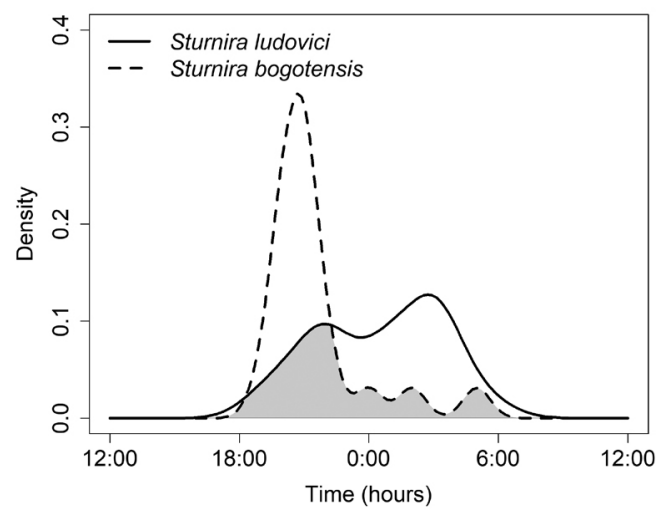

Fig. 4. Estimates of activity patterns overlap for $S$. bogotensis and $S$. Ludovici in the site of rainforest (BachuéReserve). The shaded area represents the overlap coefficient $(\Delta 1)$.
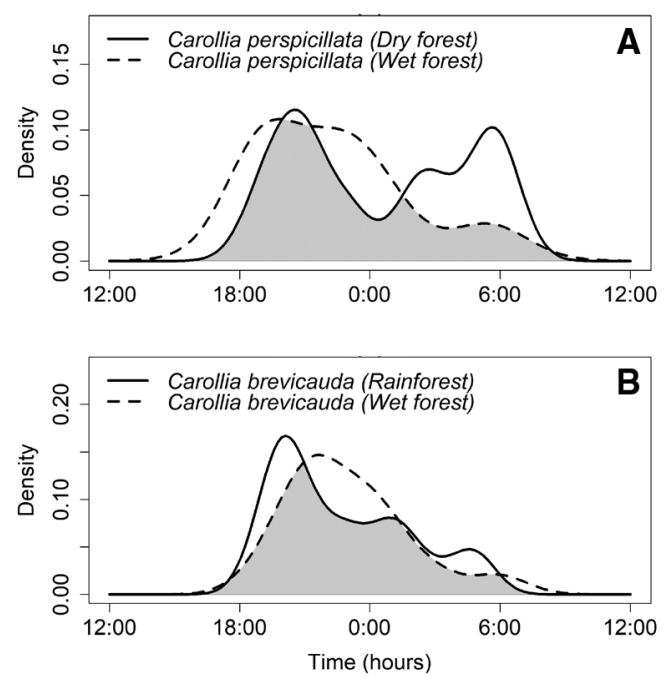

Fig. 5. Estimates of activity patterns overlap for frugivorous bats between localities. A. C. perspicillata in wet forest (Pericos Community Reserve) and dry forest (El Vínculo Regional Park). B. C. brevicauda wet forest (Pericos Community Reserve) and rainforest (BachuéReserve). The shaded area represents the overlap coefficient $\left(\Delta_{1}\right)$.

higher activity at the beginning of the night and a gradual decrease after (Fig. 5B).

We found evidence for an association between the temporal overlap and traits related to ecological similarity in some sites with high effect sizes indicating moderate to strong correlations $(\mathrm{R}>0.64)$ but no significant due to 
TABLE 4

Mean hourly overlap (95\% confidence interval) in temporal activity between the most abundant species of frugivorous bats in a rainforest (Bachué Reserve)

\begin{tabular}{lcccc}
\hline \multicolumn{1}{c}{ Species (sp.) } & $\begin{array}{c}\text { Carollia } \\
\text { brevicauda }\end{array}$ & $\begin{array}{c}\text { Dermanura } \\
\text { cf. anderseni }\end{array}$ & $\begin{array}{c}\text { Sturnira } \\
\text { bogotensis }\end{array}$ & $\begin{array}{c}\text { Sturnira } \\
\text { ludovici }\end{array}$ \\
\hline Carollia brevicauda & 1 & $0.764(0.474-0.930)$ & $0.666(0.472-0.863)$ & $0.741(0.560-0.89)$ \\
Dermanura cf. Anderseni & & 1 & $0.694(0.339-0.900)$ & $0.718(0.354-0.915)$ \\
Sturnira bogotensis & & & 1 & $0.456(0.269-0.677)$ \\
Sturnira ludovici & & & & 1 \\
\hline
\end{tabular}

TABLE 5

Summary of Mantel test applied to assemblages of frugivorous bats comparing effects of abundance, body mass, and phylogenetic distance into temporal segregation estimated by the hourly overlap in the temporal activity

\begin{tabular}{lcccccc}
\hline \multirow{2}{*}{ Locality } & \multicolumn{2}{c}{ Abundance } & \multicolumn{2}{c}{ Body mass } & \multicolumn{2}{c}{ Phylogenetic distance } \\
\cline { 2 - 6 } & $\mathrm{R}$ & P-value & $\mathrm{R}$ & $\mathrm{P}$-value & $\mathrm{R}$ & P-value \\
\hline Vínculo & $\mathbf{0 . 6 4 7}$ & $\mathbf{0 . 1 6 6}$ & $\mathbf{0 . 6 5 7}$ & $\mathbf{0 . 0 8 3}$ & 0.085 & 0.5 \\
Pericos & -0.344 & 0.866 & -0.037 & 0.638 & -0.354 & 0.874 \\
Bachué & -0.058 & 0.485 & 0.486 & 0.167 & $\mathbf{0 . 8 2 9}$ & $\mathbf{0 . 0 8 3}$ \\
\hline
\end{tabular}

The correlations with marginally significant associations are highlighted in bold.

the small sample sizes involved in the tests. We found a positive and marginally significant association of temporal overlap $\left(\Delta_{1}\right)$ with abundance $(\mathrm{R}=0.647, \mathrm{P}=0.166)$ and body mass $(\mathrm{R}=0.657, \mathrm{P}=0.083)$ in El Vinculo, and with phylogenetic distance in Bachué $(\mathrm{R}=0.829, \mathrm{P}=$ 0.083) (Table 5). On the other hand, we did not find associations of temporal overlap with body mass, abundance, or phylogenetic similarity in the assemblage of Pericos. Thus, these results indicate that species similar in abundance, size, and phylogenetic history tend to have less overlap in activity patterns.

\section{DISCUSSION}

We found differences in the temporal activity pattern of frugivorous bats assemblages among sites, revealed by a difference greater than $10 \%$ in activity patterns of assemblages. We also found differences in activity patterns between species in each locality and populations of the same species among sites. Finally, we found that species similar in abundance, size, and phylogenetic history, tend to have less overlap in activity patterns. Consequently, our results suggest that (1) local biotic and abiotic conditions may influence variation in the activity patterns between assemblages and populations of the same species, and (2) ecologically similar species tend to present less overlap in their activity patterns. Thus, our results provide empirical support for the role of segregation in temporal activity as a mechanism that allows the coexistence of ecologically similar species.

We obtained a low capture rate of phyllostomid bats that contrasts with studies in other Neotropical sites (La Val, 1970), but it is consistent with previous studies at Reserva Pericos (Zapata-Mesa et al., 2017) and El Vinculo (Velásquez-Roa \& Murillo-García, 2019) and in another wet forest at similar altitude on the Western Andes of Colombia (Ferro-Muñoz et al., 2018). As we expected, the assemblages of frugivorous bats showed spatial variations in their activity patterns. Given the high energy cost and predation risk implicit in bat flight (Erkert, 1982; Norberg et al., 1993), the ecological tendency is to minimize foraging time (Howe, 1979). On the other hand, frugivores could require more time to satisfy their daily energetic requirements than other trophic 
guilds since their food can have a higher proportion water and indigestible materials (Erkert, 1982; Thomas, 1984). Bats spend most of the daytime in shelters, a period in which they do not feed, so they are expected to leave their shelters early in the night to solve this situation of energy stress (Aguiar et al., 2014; Ortêncio Filho et al., 2010). The frugivorous bats of the three assemblages showed the highest activity during the first hours of the night. This pattern is widely documented in neotropical bats and can result from synergistic factors (Erkert, 1982; Marinho Filho \& Sazima, 1989; Pedro \& Taddei, 2002; Verde et al., 2018). In this sense, the activity time, which initiates with the emergence from shelters, is also influenced by the diet of the species and the shelter's proximity to food sources (Ortêncio Filho et al., 2010). With an activity peak early in the night, the unimodal pattern observed in Pericos and Bachué is characteristic of frugivorous species (De Souza \& Marinho-filho, 2004; Erkert, 1982; Ramirez-Pulido \& Armella, 1987). However, frugivorous bats at El Vínculo showed a bimodal pattern of activity, which peaks just after sunset and before sunrise. The availability of food sources can be low in El Vínculo since it is a small fragment of tropical dry forest, which could probably force frugivorous bats to perform a second feeding trip to supply their daily energy requirement. Alternatively, variations in activity between assemblages may correspond to species responses to differences between study sites in other ecological factors, such as vegetation coverage, luminosity, etc.

When there is a high overlap in one of the dimensions of the niche (for example, in the food source), a low overlap is expected in other dimensions (such as the foraging schedule) (Pianka, 1974). Experimental studies have induced temporal changes of activity in small mammals attributed to competition, resulting in a species being restricted to a less favorable activity time due to the influence of the more dominant species (Ziv et al., 1993). Likewise, previous studies have reported differences in the temporal activity patterns of frugivorous bats (Aguiar \& Marinho-Filho,
2004; Zeppelini et al., 2017). Some authors suggest that this difference in the temporal activity does not result from competition (Aguiar \& Marinho-Filho, 2004; Zeppelini et al., 2017), even though exploitation competition has been reported between species of Neotropical frugivorous bats (Bonaccorso et al., 2007). However, differences in activity patterns between frugivorous bats may suggest an effect of competition, with the early emergence of a species to avoiding competition during foraging with the more dominant and larger species (Bonaccorso et al., 2007).

In habitats with limited resources, it is highly probable to expect competition among bats for the fruits available a given night (Bonaccorso et al., 2007). Consequently, the bats that emerge early can successfully find food (Bonaccorso et al., 2007) since the availability of ripe fruits decreases throughout the night; consumed fruits are not renewed on the same night (Aguiar \& Marinho-filho, 2004; Heithaus et al., 1975). Thus, a species can roost closer to the feeding patches or advance its emergence time to avoid competition with other ecologically similar species (Bonaccorso et al., 2007). We considered that a $10 \%$ difference in temporal activity between two species could be enough to suggest temporal segregation. In agreement with the hypothesis of temporal segregation of resources between the species of the same guild, we found differences of at least $10 \%$ in the activity patterns of pairs of sympatric species in the three habitats; it suggests that frugivorous bats alter their activity periods in order to reduce competition with similar species. We found marked differences between the activity patterns of species with similar body mass such as $C$. castanea $-R$. alethina in the wet forest site and between species of the same genus such as S.ludovici - $S$. bogotensis in the rainforest site.

Across the Neotropic region, there is a high association between genera of plants and frugivorous bats. Bats of the genus Artibeus have an affinity for the fruits of plants of the genus Cecropia, bats of Dermanura for Ficus, bats Carollia for Piper, and bats of Sturnira for 
Solanum (Agnarsson et al., 2011; Estrada \& Fleming, 1986; Howell \& Burch, 1974; Muller \& Reis, 1992), with species showing some discrepancies at specific sites (Bonaccorso, 1979; Handley et al., 1991). These associations have been previously found in our study sites (El Vinculo: Velásquez-Roa \& Murillo-García, 2019; Pericos: Zapata-Mesa et al., 2017), which may reduce intergeneric competition and explain the high overlap in the activity patterns we observed inside the local assemblages. Besides diet, vertical stratification in neotropical bats assemblages (Delaval et al., 2005; Pereira et al., 2010; Silva et al., 2020) may be a mechanism of spatial segregation. It can reduce the probability of encounters between bats foraging mainly in the canopy (i.e., Artibeus) and the understory (i.e., Carollia, Sturnira), reducing competition intensity. On the other hand, foraging strategies can also promote coexistence (Delaval et al., 2005; Soriano, 2000). Nomadic frugivores like species of Sternodermatinae subfamily (except Sturnira) feed on trees distant from each other by foraging over large areas tracking resource availability, whereas sedentary frugivores forage over short distances by staying in permanent roosts (Soriano, 2000). Therefore, the combination of spatial and temporal segregation with behavioral strategies may lead to coexistence and be critical to determining the structure of frugivorous bats' assemblages, as has been reported for insectivorous species (Razgour et al., 2011).

As predicted, we found an association of temporal overlap with traits that suggest ecological similarity: abundance, body size, and phylogenetic closeness. As species differ more in body mass and phylogenetic history, they increase their temporal overlap, suggesting a tendency for ecologically similar species to segregate temporally. This effect is significant among the most abundant species, which may have a greater probability of interacting with each other (Meyer \& Kalko, 2008; Patterson et al., 2003). However, we did not find these associations for all traits in all the sites studied, suggesting that the degree of ecological similarity between species may occur through different mechanisms or that the structuring mechanisms differ between sites or ecosystems. On the other hand, predation risk is a fundamental aspect considering activity patterns, particularly for small species such as bats. The segregation of activity times can reduce predation risk since bat predators can detect the aggregations of foraging bats in fruiting plants (Breviglieri et al., 2013; Howe, 1979; Thies et al., 2006), so visiting plants sporadically at night could reduce the chances of being predated.

The study of resource partitioning in space and time is vital to understand how interspecific competition can allow the stable coexistence of species with similar ecological characteristics (Bonaccorso et al., 2007; Schoener, 1974). Nevertheless, the effect of time partitioning on intra-guild competition has been poorly studied. We found that temporal activity patterns of Neotropical frugivorous bats are variable between assemblages, sympatric species, and populations of the same species. Activity patterns respond to the interaction of multiple factors, ranging from the supply of resources to interactions with other species. The results suggest that the association between plant and bat genera (i.e., Carollia Piper, Sturnira - solanum), which may reduce intergeneric bat competition, may partially explain the high overlap in the activity patterns we observed. Besides, although the highest activity is conserved at the beginning of the night, the phylogenetic factor does not seem to influence the conservation of the activity patterns in bats, unlike other groups such as rodents (Castro-Arellano \& Lacher, 2009). Finally, we found that species with similar size, abundance, and evolutionary history differentiate their activity patterns. Thus, our study provides empirical support for a trend towards temporal segregation in the activity of ecologically similar species, which may represent a mechanism that promotes coexistence. Consequently, our results contrast with those pointing out that temporal activity patterns of sympatric species do not respond to interspecific competition. 
Ethical statement: the authors declare that they all agree with this publication and made significant contributions; that there is no conflict of interest of any kind; and that we followed all pertinent ethical and legal procedures and requirements. All financial sources are fully and clearly stated in the acknowledgements section. A signed document has been filed in the journal archives.

\section{ACKNOWLEDGMENTS}

We would like to thank to thee staff of La Fundación Farallones, El Parque Nacional Natural Farallones de Cali, el Instituto para la Investigación y la Preservación del Patrimonio Cultural y Natural del Valle del Cauca (INCIVA) and the Medio y Alto Dagua Community Council for their logistic collaboration and for allowing access to the sampling areas. Thanks to Cristhian Calvache, Andrea Bernal, Christian Cabrera, Oscar Cuellar, Julio Salinas, Sergio Tabares, Andrés Ocampo and Alejandro Montoya for their unconditional support during the fieldwork. Finally, we thank the Graduate Biology program of Universidad del Valle for providing funds to cover publication expenses.

\section{RESUMEN}

\section{Distribución del tiempo entre murciélagos frugívoros neotropicales: efectos de la filogenia, el tamaño corporal y la abundancia}

Introducción: La partición de recursos es esencial para determinar la riqueza y composición de especies en las comunidades naturales. Sin embargo, la segregacion temporal ha sido cuestionada como un mecanismo que promueve la coexistencia de especies ecológicamente similares.

Objetivo: Con el fin de determinar la importancia de la segregación en los patrones de actividad, como mecanismo que promueve la coexistencia; se compararon los patrones de actividad de murciélagos frugívoros neotropicales.

Métodos: Se capturaron murciélagos con redes de niebla desde el atardecer hasta el amanecer en tres localidades (bosque seco tropical, bosque muy húmedo y bosque lluvioso submontano) con el fin de calcular los patrones de actividad de las especies empleando la estimación de densidad Kernel. Se utilizó el coeficiente de superposición $(\Delta)$ para comparar patrones de actividad entre: (1) ensamblajes de murciélagos de los sitios de estudio, (2) especies frugívoras en el mismo sitio, y (3) poblaciones de la misma especie en diferentes sitios.

Resultados: Se encontraron variaciones geográficas en los patrones de actividad de los ensamblajes en las tres localidades. Asimismo, se encontraron variaciones en los patrones de actividad entre especies en cada sitio y entre poblaciones en diferentes sitios. Determinamos que la superposición en los patrones de actividad disminuyó a medida que las especies estaban más relacionadas filogenéticamente, similares en abundancia y tamaño corporal; lo que sugiere una tendencia hacia la segregación temporal de especies ecológicamente similares.

Conclusión: Estos resultados proveen apoyo empírico del papel de la segregación temporal en los patrones de actividad como un mecanismo que promueve la coexistencia de especies ecológicamente similares en la naturaleza.

Palabras clave: competencia; traslape de nicho; segregación temporal; segregación ecológica; especies ecológicamente similares; coexistencia de especies.

\section{REFERENCES}

Agnarsson, I., Zambrana-Torrelio, C. M., Flores-Saldana, N. P., \& May-Collado, L. J. (2011). A time-calibrated species-level phylogeny of bats (Chiroptera, Mammalia). PLoS Currents, 1900(3), 1-31. https://doi. org/10.1371/currents.RRN1212

Aguiar, L. M. D. S., Bernard, E., \& Machado, R. B. (2014). Habitat use and movements of Glossophaga soricina and Lonchophylla dekeyseri (Chiroptera : Phyllostomidae) in a Neotropical savannah. Zoologia (Curitiba), 31(3), 223-229.

Aguiar, L. M. D. S., \& Marinho-Filho, J. (2004). Activity patterns of nine phyllostomid bat species in a fragment of the Atlantic forest in southeastern Brazil. Revista Brasileira de Zoologia, 21(2), 385-390. https://doi.org/10.1590/s0101-81752004000200037

Bonaccorso, F. J. (1979). Foraging and reproductive ecology in a Panamanian bat community. Bulletin Florida State Museum, Biological Sciences, 4, 359-408.

Bonaccorso, F. J., Winkelmann, J. R., Shin, D., Agrawal, C. I., Aslami, N., Bonney, C., Hsu, A., Jekielek, P. E., Knox, A. K., Kopach, S. J., Jennings, T. D., Lasky, J. R., Menesale, S. A., Jeannine, H., Rutland, J. A., Sessa, A. K., Zhaurova, L., \& Kunz, T. H. (2007). Evidence for exploitative competition: comparative foraging behavior and roosting ecology of shorttailed fruit bats (Phyllostomidae). Biotropica, 39(2), 249-256. https://doi.org/10.5897/AJB2014.14258

Breviglieri, C. P., Piccoli, G., Uieda, W., \& Romero, G. (2013). Predation-risk effects of predator identity on the foraging behaviors of frugivorous bats. Oecologia, 173(3), 905-912. https://doi.org/10.1007/ s00442-013-2677-9 
Brown, J. H. (1968). Activity patterns of some neotropical bats. Journal of Mammalogy, 49(4), 754-757. https:// doi.org/10.2307/1378737

Cadelo-Cabrera, D., \& Parra-Valencia, G. (2007). Caracterización de la vegetación de bosque seco tropical en la estación biológica El Vínculo y parches vecinos a su zona de amortiguación - Municipio de Buga. Cespedesia, 29(84-85), 77-100.

Castro-Arellano, I., \& Lacher, T. E. (2009). Temporal niche segregation in two rodent assemblages of subtropical Mexico. Journal of Tropical Ecology, 25(6), 593603. https://doi.org/10.1017/S0266467409990186

Chase, J. M., \& Leibold, M. A. (2003). Ecological niches: Linking classical and contemporary approaches. The University of Chicago Press.

Colorado-Zuluaga, G. (2015). How ecological communities are structured: A review on ecological assembly rules. Revista EIA, 12(24), 27-53. https://doi. org/10.24050/reia.v12i24.873

De Souza, L., \& Marinho-filho, J. (2004). Activity patterns of nine phyllostomid bats species in a fragment of atlantic forest in Brazil. Revista Brasileira de Zoología, 21(2), 385-390. https://doi.org/10.1590/ S0101-81752004000200037

Delaval, M. D., Enry, M. H., \& Ominique, P. C. H. (2005). Interspecific competition and niche partitioning: example of a neotropical rainforest bat community. Revue d'écologie (Terre Vie), 60, 149-166.

Diamond, J. (1975). Assembly of species communities. In M. L. Cody \& J. M. Diamond (Eds.), Ecology and evolution of communities. Harvard University Press.

Díaz, M. M., Solari, S., Aguirre, L. F., Aguiar, L. M. S., \& Barquez, R. M. (2016). Clave de identificación de los murciélagos de Sudamérica. Programa de Conservación de Murciélagos, Argentina.

Erkert, H. G. (1982). Ecological aspects of bat activity rhythms. In Ecology of bats (pp. 201-242). Springer.

Estrada, A., \& Fleming, T. H. (Eds.). (2012). Frugivores and seed dispersal (Vol. 15). Springer Science \& Business Media.

Ferro-Muñoz, N., Giraldo, A., \& Murillo García, O. E. (2018). Composition, trophic structure and activity patterns of the understory bats of the bitaco forest reserve. Acta Biologica Colombiana, 23(2), 170-178. https://doi.org/10.15446/abc.v23n2.64062

Funagua, C. (2010). Aunar esfuerzos técnicos y económicos para realizar el análisis preliminar de la representatividad ecosistémica, a través de la recopilación, clasificación y ajuste de información primaria y secundaria con rectificaciones de campo del mapa de ecosistemas. Corporación Autónoma del Valle del Cauca.
Fundación Farallones. (2013). Fundación Farallones (Sitio web) https://www.fundacionfarallones.org/

Hagen, E. M., \& Sabo, J. L. (2014). Temporal variability in insectivorous bat activity along two desert streams with contrasting patterns of prey availability. Journal of Arid Environments, 102, 104-112. https://doi. org/10.1016/j.jaridenv.2013.11.016

Halle, N. C., \& Stenseth, S. (2000). Activity patterns in small mammals: an ecological approach. Springer. https://doi.org/10.1007/978-3-642-18264-8

Handley, C. O., Wilson, D. E., \& Gardner, A. L. (1991). Demography and natural history of the common fruit bat, Artibeus jamaicensis, on Barro Colorado Island, Panamá. Smithsonian Contributions to Zoology, 511, 1-173. https://doi.org/10.5479/si.00810282.511

Heithaus, E. R., Fleming, T. H., \& Opler, P. A. (1975). Foraging patterns and resource utilization in seven species of bats in a seasonal tropical forest. Ecological Society of America, 56(4), 841-854.

Holdridge, L. R. (1967). Life zone ecology. Tropical Science Center.

Holt, R. D. (2001). Species coexistence. In Encyclopedia of Biodiversity (Vol. 5). University of Florida. https:// doi.org/10.1016/B978-0-12-384719-5.00025-3

Howe, H. F. (1979). Fear and frugivory. The American Naturalist, 114(6), 925-931. https://doi. org/10.1086/283540

Howell, D. J., \& Burch, D. (1974). Food habits of some Costa Rican bats. Revista de Biología Tropical, 21(2), 281-294.

Klatt, B. J., Getz, L. L., \& McGuire, B. (2015). Interspecific interactions and habitat use by prairie voles (Microtus ochrogaster) and meadow voles ( $M$. pennsylvanicus). The American Midland Naturalist, 173(2), 241-252. https://doi.org/10.1674/amid-173-02-241-252.1

Kronfeld-Schor, N., \& Dayan, T. (2003). Partitioning of time as an ecological resource. Annual Review of Ecology, Evolution, and Systematics, 34(1), 153-181. https:// doi.org/10.1146/annurev.ecolsys.34.011802.132435

Kuenzi, A. J., \& Morrison, M. L. (2003). Temporal patterns of bat activity in Southern Arizona. The Journal of Wildlife Management, 67(1), 52-64. https://doi. org/10.2307/3803061

Kunz, T. H. (1973). Resourse utilization temporal and spatial components of bat activity. Journal of Mammalogy, 54(1), 14-32.

La Val, R. (1970). Banding returns and activity periods of some Costa Rican bats. The Southwestern Naturalists, 15(1), 1-10. https://doi.org/10.2307/3670196 
Lang, A. B., Kalko, E. K. V., Römer, H., Bockholdt, C. \& Dechmann, D. K. N. (2005). Activity levels of bats and katydids in relation to the lunar cycle. Oecologia, 146(4), 659-666. https://doi.org/10.1007/ s00442-005-0131-3

Linkie, M., \& Ridout, M. S. (2011). Assessing tigerprey interactions in Sumatran rainforests. Journal of Zoology, 284(3), 224-229. https://doi. org/10.1111/j.1469-7998.2011.00801.x

López-González, C., Presley, S. J., Lozano, A., Stevens, R. D., \& Higgins, C. L. (2012). Metacommunity analysis of mexican bats: environmentally mediated structure in an area of high geographic and environmental complexity. Journal of Biogeography, 39(1), 177-192. https://doi.org/10.1111/j.1365-2699.2011.02590.x

Marinho Filho, J. S., \& Sazima, I. (1989). Activity patterns of six phyllostomid bats species in southeastern Brazil. Revista Brasileira de Biologia, 49(3), 777-782.

Meredith, M., \& Ridout, M. (2014). Overlap: Estimates of Coefficient of Overlapping for Animal Activity Patterns (Version 0.3.0., R package). https://cran.rproject.org/web/packages/overlap/index.html

Meredith, M., \& Ridout, M. (2017). Overview of the overlap package. $R$ Project, 1-9. from https://cran.rproject.org/web/packages/overlap/index.html

Meyer, C. F. J., \& Kalko, E. K. V. (2008). Bat assemblages on Neotropical land-bridge islands: nested subsets and null model analyses of species co-occurrence patterns. Diversity and Distributions, 14(4), 644-654 https://doi.org/10.1111/j.1472-4642.2007.00462.x

Milne, D. J., Fisher, A., Rainey, I., \& Pavey, C. R (2005). Temporal patterns of bats in the Top End of the Northern Territory, Australia. Journal of Mammalogy, 86(5), 909-920. https://doi. org/10.1644/1545-1542(2005)86[909:TPOBIT]2.0. $\mathrm{CO} ; 2$

Muller, M. F., \& Reis, N. R. (1992). Partição de recursos alimentares entre quatro espécies de morcegos frugívoros (Chiroptera, Phyllostomidae). Revista Brasileira de Zoologia, 9(3-4), 345-355.

Nagy-Reis, M. B., Iwakami, V. H. S., Estevo, C. A., \& Setz, E. Z. F. (2018). Temporal and dietary segregation in a neotropical small-felid assemblage and its relation to prey activity. Mammalian Biology, 95, 1-8. https:// doi.org/10.1016/j.mambio.2018.12.005

Norberg, U. M., Kunz, T. H., Steffensen, J. F., Winter, Y., \& von Helversen, O. (1993). The cost of hovering and forward flight in a nectar-feeding bat, Glossophaga soricina, estimated from aerodynamic theory. The Journal of Experimental Biology, 182, 207-227.

O'Donnell, C. F. J. (2010). Influence of season, habitat , temperature, and invertebrate availability on nocturnal activity of the New Zealand long - tailed bat
(Chalinolobus tuberculatus). New Zealand Journal of Zoology, 27(3), 207-221. https://doi.org/10.1080/ 03014223.2000 .9518228

Oksanen, A. J., Blanchet, F. G., Friendly, M., Kindt, R., Legendre, P., Mcglinn, D., Minchin, P. R., Hara, R. B. O., Simpson, G. L., Solymos, P., Stevens, M. H. H., \& Szoecs, E. (2017). Package 'vegan'. (R package) https://cran.r-project.org/web/packages/vegan/ index.html

Ortêncio Filho, H., Reis, N., \& Minte-Vera, C. (2010). Time and seasonal patterns of activity of phyllostomid in fragments of a stational semidecidual forest from the upper Paraná River, Southern Brazil. Brazilian Journal of Biology, 70(4), 937-945. https://doi. org/10.1590/S1519-69842010000500004

Patterson, B. D., Willig, M. R., \& Stevens, R. D. (2003). Trophic strategies, niche partitioning, and patterns of ecological organization. In T. H. Kunz \& M. B. Fenton (Eds.), Bat ecology (pp. 536-579). University of Chicago Press.

Pedro, W. A., \& Taddei, V. A. (2002). Temporal distribution of five bat species (Chiroptera, Phyllostomidae) from Panga Reserve, south-eastern Brazil. Revista Brasileira de Zoologia, 19(3), 951-954. https://doi. org/10.1590/S0101-81752002000300033

Pereira, M. J. R., Marques, J. T., \& Palmeirim, J. M. (2010). Vertical stratification of bat assemblages in flooded and unflooded Amazonian forests. Current Zoology, 56(4), 469-478. https://doi.org/10.1093/ czoolo/56.4.469

Pianka, E. R. (1974). Niche overlap and diffuse competition. Proceedings of the National Academy of Sciences, 71(5), 2141-2145. https://doi.org/10.1073/ pnas.71.5.2141

R Core Team. (2017). $R$ : A language and environment for statistical computing. R Foundation for Statistical Computing. Vienna, Austria. https://www.R-project. org/

Ramirez-Pulido, J., \& Armella, M. A. (1987). Southwestern association of naturalists activity patterns of neotropical bats (Chiroptera: Phyllostomidae) in Guerrero, Mexico. The Southwestern Naturalist, 32(3), 363-370.

Razgour, O., Korine, C., \& Saltz, D. (2011). Does interspecific competition drive patterns of habitat use in desert bat communities? Oecologia, 167(2), 493-502. https://doi.org/10.1007/s00442-011-1995-z

Rocha, R., López-Baucells, A., Farneda, F. Z., Ferreira, D. F., Silva, I., Acácio, M., Palmeirim, J. M., \& Meyer, C. F. J. (2020). Second-growth and small forest clearings have little effect on the temporal activity patterns of Amazonian phyllostomid bats. Current Zoology, 66(2), 145-153. https://doi.org/10.1093/ $\mathrm{cz} / \mathrm{zoz} 042$ 
Rojas, D., Warsi, O. M., \& Dávalos, L. M. (2016). Bats (Chiroptera: Noctilionoidea) challenge a recent origin of extant neotropical diversity. Systematic Biology, 65(3), 432-448. https://doi.org/10.1093/sysbio/ syw011

Rothenwöhrer, C., Becker, N. I., \& Tschapka, M. (2011). Resource landscape and spatio-temporal activity patterns of a plant-visiting bat in a Costa Rican lowland rainforest. Journal of Zoology, 283(2), 108-116. https://doi.org/10.1111/j.1469-7998.2010.00748.x

Santos-Moreno, A., Velásquez, E. R., \& Martínez, A. S. (2010). Efecto de la intensidad de la luz lunar y de la velocidad del viento en la actividad de murciélagos filostómidos de Mena Nizanda, Oaxaca, México. Revista Mexicana de Biodiversidad, 81(3), 839-845.

Schoener, T. W. (1974). Resource partitioning in ecological communities. Science, 185(4145), 27-39. https://doi. org/10.1126/science.185.4145.27

Silva, R. C., Silveira, M., \& Verde, R. S. (2020). Vertical stratification of phyllostomid bats assemblage (Chiroptera, phyllostomidae) in a forest fragment in Brazilian Southwestern amazon. Neotropical Biology and Conservation, 15(2), 107-120. https://doi. org/10.3897/neotropical.15.e47641

Soriano, P. J. (2000). Functional structure of bat communities in tropical rainforests and andean cloud forests selvas humedas tropicales y selvas nubladas andinas. Ecotropicos, 13(1), 1-20.

Speakman, J. R., Rydell, J., Webb, P. I., Hayes, J. P., Hays, G. C., Hulbert, I. A. R., \& Mcdevitt, R. M. (2000). Activity patterns of insectivorous bats and birds in Northern Scandinavia $\left(69^{\circ} \mathrm{N}\right)$, during continuous midsummer daylight. Oikos, 88(1), 75-86. https:// doi.org/10.1034/j.1600-0706.2000.880109.x

Thies, W., Kalko, E. K. V., \& Schnitzler, H. U. (2006). Influence of environment and resource availability on activity patterns of Carollia Castanea (Phyllostomidae) in Panama. Journal of Mammalogy, 87(2), 331338. https://doi.org/10.1644/05-mamm-a-161r1.1

Thomas, D. W. (1984). Fruit intake and energy budgets of frugivorous bats. Physiological Zoology, 57(4), 457-467.
Velásquez-Roa, T., \& Murillo-García, O. E. (2019). Influence of bat morphology on structural properties of a plant-frugivore network. Mastozoología Neotropical, 26(2), 440-451. https://doi.org/10.31687/ saremmn.19.26.2.0.23

Verde, R. S., Silva, R. C., \& Calouro, A. M. (2018). Activity patterns of frugivorous phyllostomid bats in an urban fragment in southwest Amazonia, Brazil. Iheringia. Série Zoologia, 108(0), 1-7. https://doi. org/10.1590/1678-4766e2018016

Vieira, E. M., De Camargo, N. F., Colas, P. F., Ribeiro, J. F., \& Cruz-Neto, A. P. (2017). Geographic variation in daily temporal activity patterns of a neotropical marsupial (Gracilinanus agilis). PLoS ONE, 12(1), 1-17. https://doi.org/10.1371/journal.pone.0168495

Vilella, M., Ferrandiz-Rovira, M., \& Sayol, F. (2020). Coexistence of predators in time: effects of season and prey availability on species activity within a Mediterranean carnivore guild. Ecology and Evolution, 10(20), 11408-11422. https://doi.org/10.1002/ ece 3.6778

Zapata-Mesa, N., Montoya-Bustamante, S., \& MurilloGarcía, O. E. (2017). Temporal variation in bat-fruit interactions: foraging strategies influence network structure over time. Acta Oecologica, 85, 9-17. https://doi.org/10.1016/j.actao.2017.09.003

Zeppelini, C. G., Azeredo, L. M. M., \& Lopez, L. C. S. (2019). Bats like dimmer lights: lunar phobia as a luminosity threshold phenomenon on Neotropical bats (Mammalia: Chiroptera). Acta Ethologica, 22(2), 125-128. https://doi.org/10.1007/ s10211-019-00314-w

Zeppelini, C. G., Jeronimo, I., Costa, G. K., Aguiar, M. P., \& Serramo, L. C. (2017). Description of whole-night activity patterns for neotropical bat species. Acta Chiropterologica, 19(1), 155-160.

Ziv, Y., Abramsky, Z., Kotler, B. P., \& Subach, A. (1993). Interference competition and temporal and habitat partitioning in two gerbil species. Oikos, 66(2), 237-246. https://doi.org/10.2307/3544810 